УДК 339.137

DOI: https://doi.org/10.32840/2522-4263/2020-2-24

\author{
Skorokhod Iryna \\ Candidate of Economical Sciences, Associate Professor, \\ Associate Professor at the Department \\ of International Economic Relations and Project Management \\ Lesya Ukrainka Eastern European National University
}

Khirova Viktoria Student of Master Specialty of Faculty of International Relations Lesya Ukrainka Eastern European National University

Скороход I.C. кандидат еконолічних наук, доцент, доцент кафедри міжнародних еконолічних відносин та управління проектали

Східноєвропейського національного університету імені Лесі Украйнки

Хірова В.Ю.

студентка магістратури факультету ліжнародних відносин Східноєвропейського національного університету ілені Лесі Украӥнки

\title{
METHODICAL PRINCIPLES FOR ENTERPRISE COMPETITIVENESS ESTIMATION
}

\section{МЕТОДИЧНІ ПРИНЦИПИ ОЦІНКИ КОНКУРЕНТОСПРОМОЖНОСТІ ПІДПРИЕМСТВА}

\begin{abstract}
ANNOTATION
In the article various modern methods of estimation of competitiveness of the enterprises are investigated and the unified system of classification of these methods is proposed. As competitiveness is an extremely multifaceted and complex concept that encompasses a large number of assessment methods today, there is a broad methodological basis for research in this area. However, despite the number of developments, there is no single organized system of classification of methods for assessing the competitiveness of an enterprise. Therefore, the purpose of the study is to analyze the theoretical foundations and practical aspects of assessing the competitiveness of the enterprise in terms of its methods. In particular, the classification of methods into three groups is proposed and studies of each of them are presented, the most relevant methods that belong to each group are analyzed. Also, as a result of effective study of methods of assessing the competitiveness of enterprises, within the framework of scientific work, strategies for enhancing the competitiveness of organizations in the market have been identified and analyzed. Thus, the study presents classification developments that can be used immediately for practical implementation as a strategy for the development of a particular enterprise.

Key words: competitiveness, enterprise, methods of estimation of competitiveness, classification of methods, strategy of competitiveness.
\end{abstract}

\section{АНОТАЦІЯ}

У статті досліджуються сучасні методи оцінки конкурентоспроможності підприємств та запропонована єдина система класифрікації даних методів. Актуальність даної роботи підкреслює те, що внаслідок впливу глобалізаційних та інтеграційних процесів на сьогодні єдиним критерієм ефективності та затребуваності будь-якого аспекту світового господарства $є$ його конкурентоспроможність. В умовах розвитку міжнародної торгівлі загострюється конкурентна боротьба як на внутрішніх так і на світових товарних ринках. У статті визначено, що оцінка конкурентоспроможності підприємства дає певну відносну характеристику здатності підприємства конкурувати на зовнішніх ринках. Саме конкурентоспроможність виступає агрегованим показником визначення потенційних можливостей фірми. Зважаючи на те, що конкурентоспроможність сьогодні $є$ надзвичайно багатогранним та складним поняттям, яке охоплює велику кількість аспектів, інструментів та власне методів оцінки, існує широка методологічна база досліджень цієї сфери. Проте, незважаючи на кількість наукових напрацювань, сьогодні не існує єдиної організованої системи класифрікації методів оцінки конкурентоспроможності підприємства. Саме тому метою дослідження було визначено вивчення теоретичних основ та практичних аспектів оцінки конкурентоспроможності підприємства у розрізі її методів. Зокрема, запропоновано класифрікацію методів на три групи (методи, що характеризують ринкову позицію підприємства, методи, що характеризують рівень управління підприємством, методи, що характеризують рівень фінансово-господарської активності підприємства) та представлено дослідження кожної з них. Також у науковій статті було проаналізовано найактуальніші методи, які входять до кожної зі згаданих вище груп. Виходячи з результатів ефективного вивчення методів оцінки конкурентоспроможності підприємств, у рамках наукової роботи було визначено та проаналізовано стратегії підвищення конкурентоздатності організацій на ринку. Таким чином, дослідження висвітлює класифрікаційні розробки, які можна використати для практичного втілення у ролі стратегії розвитку конкретного підприємства.

Ключові слова: конкурентоспроможність, підприємство, методи оцінки конкурентоспроможності, класифрікація методів, стратегія конкурентоспроможності.

\section{АННОТАЦИЯ}

В статье исследованы различные современные методы оценки конкурентоспособности предприятий и предложена единая система классификации данных методов. Поскольку конкурентоспособность сегодня является чрезвычайно многогранным и сложным понятием, которое охватывает большое количество методов оценки, существует широкая методологическая база исследований этой сферы. Однако, несмотря на количество наработок, сегодня не существует единой организованной системы классификации методов оценки конкурентоспособности предприятия. Поэтому целью исследования определены изучение теоретических основ и практических аспектов оценки конкурентоспособности предприятия в разрезе ее методов. В частности, предложена классификация методов на три группы и представлено исследование каждой из них, 
проанализированы актуальные методы, входящие в каждую из групп. Также в результате эффективного изучения методов оценки конкурентоспособности предприятий в рамках научной работы определены и проанализированы стратегии повышения конкурентоспособности организаций на рынке. Таким образом исследование представляет классификационные разработки, которые можно сразу использовать для практического воплощения в роли стратегии развития конкретного предприятия.

Ключевые слова: конкурентоспособность, предприятие, методы оценки конкурентоспособности, классификация методов, стратегия конкурентоспособности.

Formulation of the problem. In today's market environment, the criteria for successful enterprise development predict its strategy and capabilities, identify prospects and status of target markets. However, the main indicator of an enterprise's "weight» in the world market is its level of competitiveness. That is why the relevance of research in the field of enterprise competitiveness is increasing. The peculiarities of national and international economies development have caused the necessity and urgency of detailed researches in the field of enterprises competitiveness. It can be stated that we have a great need to analyze the mechanisms of creation and implementation of competitive strategies and methods of estimation of the competitiveness of the enterprise in various fields of activity.

The analysis of researches and publications. The study and comprehensive analysis of the phenomenon of "competitiveness of the enterprise" were researched by such national and foreign scientists as: G. Azoev, T. Vasyltsev, A. Dayan, I. Dolzhansky, R. Lupak, O. Okovkin, M. Porter, M. Sayenko, A. Strickland, J. Shkardun and other.

The authors proposed their own classification of existing methods of enterprise competitiveness estimation, but without trying to systematize them. Therefore, we consider it necessary to carry out a systematization of enterprise competitiveness estimation methods.

The purpose of the work is to improve the theoretical and organizational foundations of estimation of the competitiveness of the enterprise to develop relevant scientific and practical recommendations for improving the level of competitiveness of the organization. Achieving this led to the study of the methodological bases of enterprise competitiveness and the systematization and characterization of methods of estimation of competitiveness by different criteria.

Presentation of the main research material. There is no unified method for assessing the competitiveness of an enterprise today. Most of these methods are based on the classical theory of international division of labor. Basically, the methods of assess-

Source: [1] ing the competitiveness of an enterprise are divided by such criteria: the method of assessment, the form of presentation of the result, the degree of consideration of aspects of the functioning of the enterprise, the ability to make strategic decisions, the object of assessment, and the direction of formation of information base.

Taking into account the large number of different methods of assessing the competitiveness of an enterprise, we classified them into three main groups based on the components of the competitiveness:

1) methods that characterize the market position of the enterprise;

2) methods that characterize the level of management of the enterprise;

3) methods that characterize the level of financial and economic activity of the enterprise.

The first group of methods for assessing the competitiveness of the enterprise include formal models of research of a particular type of activity (business) of the enterprise and matrix methods (Figure 1).

Most of the methods that characterize the market position of the company stand out model of Porter's competitive advantage, which is a «rhombus of national advantages» (four determinants that determine the state of the environment within which the competitive advantages of the company are formed) and the product model of I. Ansoff, which represents an analytical tool for strategic management. It is formed by two axes (the horizontal axis - «company goods" and the vertical axis - «company markets») at the intersection of which are formed four quadrants, which determine the strategies for positioning an enterprise's product on the market [2]

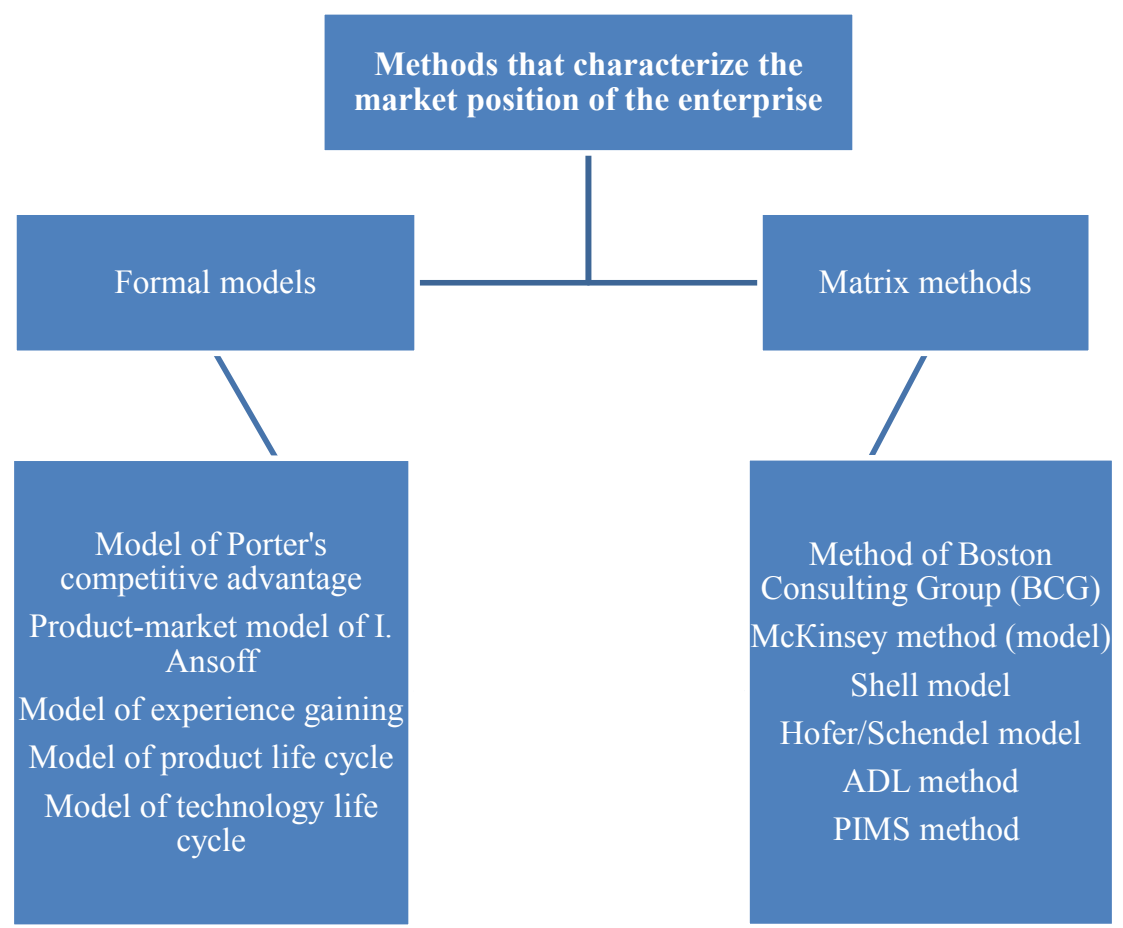

Figure 1. The structure and varieties of methods that characterize the market position of the enterprise 
Model of product life cycle allows us to formulate a strategy for the production of a set of products that are at different stages of the development of an individual enterprise. The model preserves and consolidates the competitive advantages of the enterprise. It is based on the concept of life cycle, which gives an opportunity to assess the level of technology development and the results of their use, which contributes to the optimal allocation of funds and their investment in advanced production technologies [2].

The Boston Consulting Group method is also noteworthy, which is based on the BCG matrix, which is a method of developing strategic alternatives to the enterprise within its individual strategic economic elements and business. It allows to determine the strategic position for each economic element (line of business, strategic area of management, product) of the enterprise and, based on the analysis of this position, to choose the optimal strategy for the enterprise to produce and sell products between different strategic and economic elements [3].

Formal methods are useful to analyze the specialized enterprises or/and to develop strategic alternatives for the development of the enterprise. Matrix methods make sense to apply, mainly, to enterprises with diversified product range, the state of which on the market can be determined by diagnostics in relation to its competitors and by diagnostics of the assortment structure of the enterprise's products in relation to the market situation [4].

The second group of methods for assessing the competitiveness of the enterprise (those that characterize the level of management of the enterprise) include:

- SWOT Strategic Analysis Method;

- SPACE Strategic Analysis Method;

- Expert evaluation method;

- Method of mapping strategic groups.

Considering the characteristics of these methods, presented in Table 1, we can conclude that their main advantage is that they allow to assess the competitive position of the enterprise through the effectiveness of its management. These methods show, which managerial decisions have allowed to take a particular competitive position. The methods that characterize the level of management of the enterprise are also used to analyze the market of the industry to which the organization belongs. Based on the mentioned methods, it is possible to conduct a detailed research of the market environment in which the enterprise operates and to identify the main shortcomings and obstacles to its management, which reduce the competitiveness of the organization.

The third group of methods that characterize the level of financial and economic activity of the enterprise are the methods of financial and economic analysis and methods of forecasting the financial condition of the enterprise:

- Extrapolation method;

- Method of terms of turnover;

- Method of budgeting;

- Method of forecasting.

The characteristics of each of these methods of assessing the competitiveness of the enterprise are presented in Table 2. The task of this group of methods is to assess the efficiency of the financial condition and budget sphere of the enterprise and to develop the planned budgets of the organization. It is difficult to overestimate the importance of methods of forecasting the financial condition of an enterprise, because without analysis of the financial component, it is impossible to have any effective business activity and its successful and profitable functioning.

It should also be noted that the methods of assessing the competitiveness of an enterprise can be classified by the form of presentation of the results of the assessment:

1) Graphic methods (based on the construction of «Radial Diagram of Competitiveness» or «Polygon of Competitiveness»; the advantage of this group of methods is the ease of perception and clarity of the image).

2) Matrix methods (based on the use of matrices built on the principle of coordinate system: the vertical axis defers the growth rate of the market

Methods that characterize the level of enterprise management

Table 1

\begin{tabular}{|l|l|}
\hline \multicolumn{1}{|c|}{ Method } & \multicolumn{1}{c|}{ Characteristic } \\
\hline $\begin{array}{l}\text { SWOT Strategic } \\
\text { Analysis Method }\end{array}$ & $\begin{array}{l}\text { SWOT analysis methodology identifies opportunities and threats of the external } \\
\text { environment, strengths and weaknesses of the internal environment, establishing } \\
\text { relationships between them on the basis of matrix, identifying strategic problems and } \\
\text { alternatives to the development of the organization. This analysis makes possible to } \\
\text { consider all possible pair combinations between threats, opportunities, strengths and } \\
\text { weaknesses. The established links will be used to shape the organization's strategy. }\end{array}$ \\
\hline $\begin{array}{l}\text { SPACE Strategic } \\
\text { Analysis Method }\end{array}$ & $\begin{array}{l}\text { In the SPACE matrix refined strategies are shown in the form of a set of typical strategic } \\
\text { decisions corresponding to different specific positions of the direction vector of the action } \\
\text { of a particular enterprise., in other words, that is a set of specific scenarios for a vector- } \\
\text { specific (competitive, aggressive, defensive, or conservative) enterprise strategy. }\end{array}$ \\
\hline $\begin{array}{l}\text { Expert evaluation } \\
\text { method }\end{array}$ & $\begin{array}{l}\text { A method of predicting and evaluating the future results of an enterprise strategy based } \\
\text { on specialist forecasts. When applying the method of expert assessments, a special group } \\
\text { of experts (5-7 persons) is interviewed in order to identify certain variables needed to } \\
\text { evaluate the issue. }\end{array}$ \\
\hline $\begin{array}{l}\text { Method of mapping } \\
\text { strategic groups }\end{array}$ & $\begin{array}{l}\text { Represents a map of strategic groups of competitors in order to identify the } \\
\text { organizations that are the closest competitors of the studied enterprise. The map } \\
\text { complements and specifies information about industry competition. }\end{array}$ \\
\hline Source: [3-6] & \multicolumn{1}{|c|}{}
\end{tabular}


Table 2

Methods that characterize the level of financial and economic activity of the enterprise

\begin{tabular}{|l|l|}
\hline \multicolumn{1}{|c|}{ Method } & \multicolumn{1}{c}{ Characteristic } \\
\hline $\begin{array}{l}\text { Extrapolation } \\
\text { method }\end{array}$ & $\begin{array}{l}\text { Extrapolation consists in studying the formed sustainable tendencies of economic development } \\
\text { and transferring them to the future. The forecast determines the expected economic } \\
\text { development assumptions based on the hypothesis that the main factors and trends of the } \\
\text { previous period will be preserved for the forecast period, or that the direction of their } \\
\text { changes in the considered perspective can be justified and taken into account. This hypothesis } \\
\text { is based on the inertia of economic phenomena and processes. Extrapolation in general is } \\
\text { presented as a certain value of a function }\end{array}$ \\
\hline $\begin{array}{l}\text { Method } \\
\text { of terms } \\
\text { of turnover }\end{array}$ & $\begin{array}{l}\text { It is based on the study of the duration of the production and commercial cycle: inventory } \\
\text { turnover period plus receivables turnover minus payables turnover period multiplied by one- } \\
\text { are not normative and change under the influence of various factors and therefore also } \\
\text { require forecasting and clarification. }\end{array}$ \\
\hline $\begin{array}{l}\text { Method of } \\
\text { budgeting }\end{array}$ & $\begin{array}{l}\text { The budgeting method is about planning cash inflows and expenditures from all activities. } \\
\text { The calculation of variances between receipts and disbursements shows the planned change in } \\
\text { cash and provides the basis for making appropriate management decisions. }\end{array}$ \\
\hline $\begin{array}{l}\text { Method of } \\
\text { forecasting }\end{array}$ & $\begin{array}{l}\text { This method allows to identify and evaluate changes that will occur in the assets of the } \\
\text { enterprise and sources of their formation as a result of business transactions for the planned } \\
\text { period of time. Estimated reporting can be made at the end of each month, quarter and year. }\end{array}$ \\
\hline Source: [7]
\end{tabular}

capacity, the horizontal axis - the relative share of the manufacturer of products in the market).

3) Tabular methods (represent a variation of matrix methods).

4) Calculation methods (they are divided into specific methods (allow to evaluate the competitiveness of the enterprise on certain aspects of its activity) and complex methods (based on a comprehensive approach to assessing the competitiveness of the enterprise).

All these methods have some disadvantages and advantages in their practical application. It is quite obvious that the most complete information can be obtained only by the simultaneous application of several methods. As a result of the coordinated and creative work of a team of highly qualified professionals, it is possible to achieve a positive effect from the use of this or that method.
As a result of effective implementation of the methods of assessing the competitiveness of the enterprise, there are opportunities to develop strategies to improve the competitiveness of the organization in the market. In the economic literature, a number of standard strategies have been proposed to help businesses increase their competitiveness (Figure 2).

One of the most common strategies for operating an enterprise and enhancing its competitiveness is a market penetration strategy. This strategy is used when management believes that the existing market is not yet fully saturated with a particular product and plans to increase the share of sales of its products in that market. In this case, a strategy of "market capture» may be chosen while at the same time displacing the weakest competitors. However, the application of this strategy

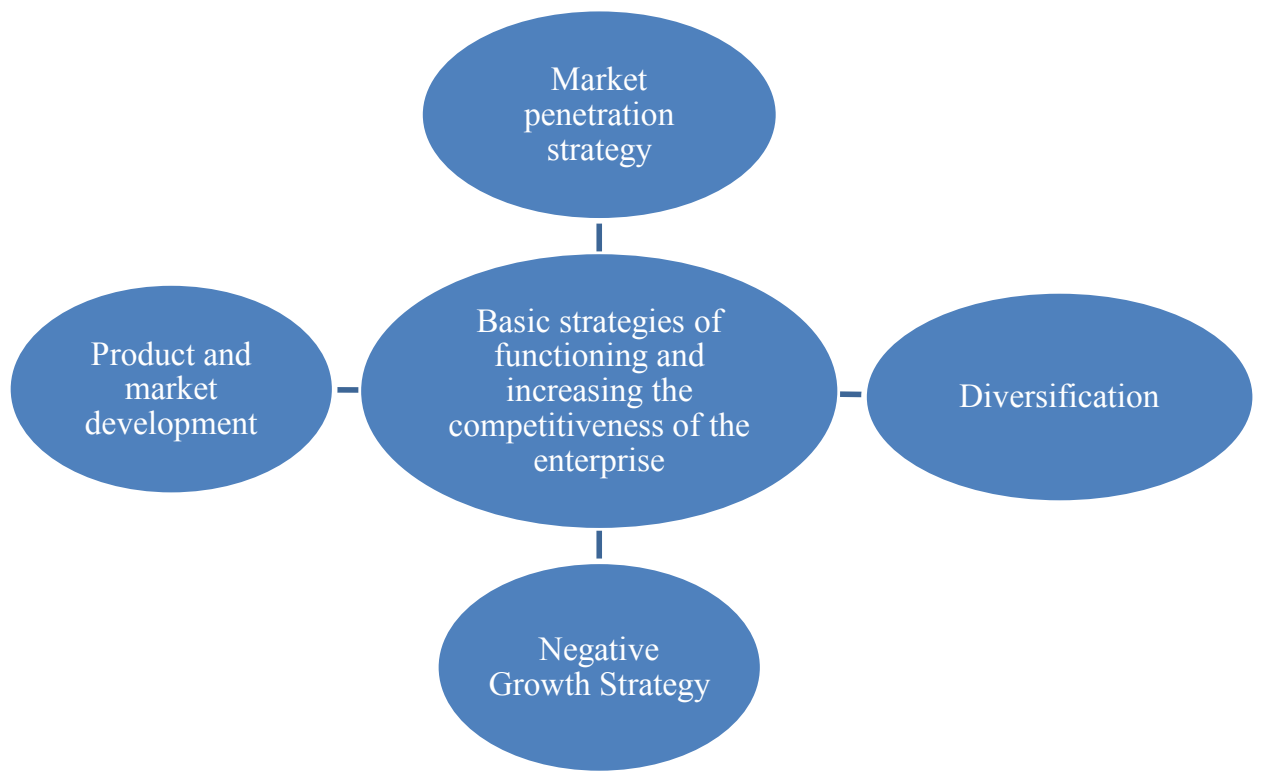

Source: [8]

Figure 2. Strategies for increasing the competitiveness of enterprises 
must be justified by the competitive advantages of the product from the price-quality standpoint.

The strategy of «market development» applies if the existing markets are already fully saturated with the company's products, and the company has the opportunity to increase production capacity and production volumes. The actions of the management of the enterprise should be directed to the search for new reliable distribution channels. A "product development» strategy is appropriate if the enterprise has a large number of competitors in the industry, and the products of competitors have the better quality at a comparable price. In this case, the management is tasked with finding new ways to improve the quality of products, with the optimal change in the cost of its production in order to increase competitiveness.

The "diversification" strategy can be used in two ways:

1) the activity of the enterprise is directed to the production of both new types of products and previously produced ones;

2) penetration into new markets of production.

Whatever direction the enterprise chooses, the process of production is already formed on the demanded types of products, as well as the realization in the existing markets does not stop. The main advantage of this strategy is that in conditions of economic instability, the activity of enterprises has a certain risk, and in the case of applying the strategy of "diversified growth" it will be divided into different activities, which will allow the enterprise to be less dependent on the unpredictability of external environment [11].

The strategy of «negative growth» («reduction strategy», «liquidation strategy») can be attributed to competitive strategies only conditionally, since it involves the reduction of production volumes and further retraining of the enterprise to new product types, respectively, transition to new markets [8].

In addition to the already discussed strategies for improving the competitiveness of the enterprise, some scientists highlight their additional options. Therefore, M. Porter puts forward a cost-leadership strategy that makes sense to become a low-cost producer of the lowest-cost products in the industry. The market niche strategy of M. Porter is also worthy of note. Its meaning is to concentrate on the main market segments, to meet the needs and demands of a defined range of consumers, either at the expense of low price or high quality.

According to the so-called biological approach, proposed by the Russian scientist L. Ramensky, distinguish violet, patent, commutative and exploratory strategies for ensuring the competitiveness of the organization [9].

The violet strategy involves mass production and delivery to the market of products acceptable to consumers at low cost of production, which allows manufacturers to set low prices based on a large amount of demand. The violet strategy is pe- culiar to large companies that dominate the market at the expense of low production costs (and therefore low prices) and high labor productivity, which is possible when organizing mass production of products aimed at the average customer.

The patent strategy is about serving narrow segments of the market with specific needs based on the organization of specialized production of products with unique characteristics. Such products are designed to gain and maintain relatively narrow market niches, within which exclusive special-purpose and very high quality goods are sold. Manufacturers and sellers of such goods sell them on the market at high prices, counting on wealthy buyers, which gives the opportunity to make significant profits with small sales volumes [9].

A commutative strategy is intended to meet the short-term needs of consumers for pax products and services. The commutative strategy aims to adapt to the constraints of local market demand, meet rapidly changing needs, and imitate novelties. Thus, the commutative strategy is characterized primarily by high flexibility. Usually, such strategy is followed by non-specialized organizations with sufficiently versatile technologies and limited production volumes, when the implementation of this strategy does not set the task of achieving high quality and selling at high prices [10].

Exploratory strategy is focused on radical innovation and market entry with a new product. Exploratory strategy relies on the competitive advantages of the organization through the introduction of constructive and technological innovations that allow to outstrip competitors in the launch and delivery of fundamentally new types of products, by investing in promising but risky innovative projects. In the case of success such projects allow not only to outperform competitors in terms of the quality of their products, but also to create new markets where they may not be afraid of competition for some time, as they are the only producers of a unique product. The implementation of such strategy requires considerable initial capital, scientific and production potential, and highly qualified team. Implementation of innovations is one of the radical means of obtaining competitive advantages, which promotes market monopolization. Examples include leaders in the aviation, automotive, electrical, and computer industries. These are companies that emerged from small businesses whose innovations in the past conquered existing markets.

Thus, each enterprise, depending on the situation in the market and inside the organization, chooses one the most suitable strategy for enhancing its own competitiveness.

Conclusions. Competitiveness of the enterprise is the ability of the organization to use all opportunities and available resources in conducting efficient and cost-effective management in a competitive market. The competitiveness of an organization is an extremely complex concept that is formed 
by several factors and indicators. Therefore, it is worth noting that in the current conditions of development and research of the competitiveness of the enterprise there is an extensive system of methods for its study and evaluation. Methods for assessing the competitiveness of an enterprise differ in scope and form of presentation. Based on the complex system of these methods, each individual company chooses its own strategy to increase its competitiveness in the market.

In general, the methods of assessing the competitiveness of an enterprise are divided by such criteria as: the method of assessment, the form of presentation of the result, the degree of consideration of aspects of the functioning of the enterprise, the ability to make strategic decisions, the object of assessment, the direction of formation of information base. The most common are rank methods, SWOT analysis, graphical, M. Porter's competitive advantage model, Boston Consulting Group method and others.

Due to such wide differentiation of methods and lack of a unified system of classification, we have decided to propose our own classification developments and unify the methods of assessing the competitiveness of the enterprise. Therefore, we have identified three groups of classification: methods that characterize the market position of the enterprise, methods that characterize the level of management of the enterprise and methods that characterize the level of financial and economic activity of the enterprise. We have researched different methods of assessing the competitiveness of an enterprise and combined them into three groups. Achieving this allow to improve the methodological bases of enterprise competitiveness, the systematization and characterization of methods of estimation of competitiveness.

\section{REFERENCES:}

1. Zhelikhovska M. B. (2009) Metody otsinky rynkovykh pozytsii pidpryiemstva [Methods of estimation of market positions of the enterprise]. Visnyk Khmelnytskoho natsionalnoho universytetu. Ekonomichni nauky. Bulletin of Khmelnytsky National University. Economic sciences, vol. 6, pp. 75-79. (in Ukrainian)

2. Metod kompleksnoho stratehichnoho analizu seredovyshcha pidpryiemstva. SWOT-analiz [Method of complex strategic analysis of enterprise environment. SWOT analysis]. Available at: http:// studopedia.com.ua/1_4399_metod-kompleksnogo-strategichnogo-analizu-seredovishcha-pidpriiemstva-SWOT---analiz.html (accessed 25 March 2020). (in Ukrainian)

3. Polinska H. A. Karta stratehichnykh hrup konkurentiv [Map of competitors' strategic groups]. Available at: http://stud.com. ua/49887/marketing/karta_strategichnih_grup_konkurentiv (accessed 19 March 2020). (in Ukrainian)

4. Karpenko L. M. (2013) Metodychni pidkhody do otsiniuvannia rivnia konkurentospromozhnosti pidpryiemstva [Methodical approaches to assessing the level of competitiveness of the enterprise]. Visnyk sotsialno-ekonomichnykh doslidzhen. Bulletin of socio-economic research, vol. 3(2), pp. 24-31. (in Ukrainian)

5. Metody prohnozuvannia finansovoi stiikosti subiektiv hospodariuvannia [Methods of forecasting financial stability of economic entities]. Available at: http://studopedia.com.ua/1_43173_metodi-prognozuvannya-finansovoi-stiykosti-subiektiv-gospodaryuvannya.html (accessed 25 March 2020). (in Ukrainian)

6. Chulakova Yu. A. (2015) Osnovy formuvannia stratehii konkurentospromozhnosti pidpryiemstva [Fundamentals of formation of enterprise competitiveness strategy]. Zhurnal naukovykh publikatsii aspirantiv ta doktorantiv. Journal of postgraduate and doctoral. Available at: http://www.jurnal.org/articles/2015/ekon68.html (accessed 19 March 2020). (in Ukrainian)

7. Encyclopedia of the Economist Recourse. Konkurentna stratehiia firmy [Competitive strategy of the firm]. Available at: http://www.grandars.ru/college/ekonomika-firmy/konkurentnaya-strategiya.html (accessed 31 March 2020). (in Russian)

8. Polinska H. A. (2015) Informatsiini systemy marketynhu [Marketing information systems]. Moscow: YURAYT. (in Russian)

9. Basilevich V. D. (2014) Ekonomichna teoriia: Politekonomiia [Economic Theory: Political Economy]. Kyiv: Znannia-Pres, 710 p. (in Ukrainian)

10. Petrovich Y. M. (2014) Ekonomika i finansy pidpryiemstv [Economics and finance of enterprises]. Lviv: Magnolia, $406 \mathrm{p}$. (in Ukrainian)

11. Melnyk A. Ye., Hevko I. O. (2010) Analiz materialnykh resursiv ta efektyvnist yikh vykorystannia [Analysis of material resources and efficiency of their use]. Available at: http://www.rusnauka.com/11_EISN_2010/Economics/64378.doc.htm (accessed 31 March 2020). (in Ukrainian)

\section{БІБЛІОГРАФІЧНИЙ СПИСОК:}

1. Желіховська М. В. Методи оцінки ринкових позицій підприємства. Вісник Хмельницького національного університету. Економічні науки. 2009. № 6. Т. 1. С. 75-79.

2. Метод комплексного стратегічного аналізу середовища підприємства. SWOT-аналіз. URL: http://studopedia.com.ua/1_4399 metod-kompleksnogo-strategichnogo-analizu-seredovishchapidpriiemstva-SWOT---analiz.html (дата звернення: 25.03.2020).

3. Полинська Г. А. Карта стратегічних груп конкурентів. URL: http://stud.com.ua/49887/marketing/karta_strategichnih_ grup_konkurentiv (дата звернення: 19.03.2020).

4. Карпенко Л. М. Методичні підходи до оцінювання рівня конкурентоспроможності підприємства. Вісник соціально-економічних досліджень. 2013. Вип. 3(2). С. 24-31.

5. Методи прогнозування фрінансової стійкості суб'єктів господарювання. URL: http://studopedia.com.ua/1_43173_ metodi-prognozuvannya-finansovoi-stiykosti-subiektivgospodaryuvannya.html (дата звернення: 25.03.2020).

6. Чулакова Ю. А. Основи формування стратегії конкурентоспроможності підприємства. Журнал наукових публікацій аспірантів та докторантів. 2015. URL: http://www.jurnal. org/articles/2015/ekon68.html (дата звернення: 19.03.2020).

7. Ресурс Енциклопедія Економіста. Конкурентна стратегія фірми. URL: http://www.grandars.ru/college/ekonomika-firmy/ konkurentnaya-strategiya.html (дата звернення: 31.03.2020).

8. Полинська Г. А. Інформаційні системи маркетингу. Москва : ЮРАЙТ, 2015.

9. Базилевич В. Д. Економічна теорія: Політекономія. Київ : Знання-Прес, 2014. 710 с.

10. Петрович Й. М. Економіка і фінанси підприємств. Львів : Магнолія, 2014. 406 с.

11. Мельник А. Є., Гевко І. О. Аналіз матеріальних ресурсів та ефективністьїхвикористання.URL:http://www.rusnauka.com/ 11_EISN_2010/Economics/64378.doc.htm (дата звернення: 31.03.2020). 